\title{
TEKNOLOGI PEMBUATAN ADSORBEN DARI LIMBAH EKSTRAKSI BIOSILIKA SEKAM PADI
}

\author{
Prima Luna, Hoerudin, Sri Usmiati, Sunarmani \\ Balai Besar Penelitian dan Pengembangan Pascapanen Pertanian \\ Email: primaluna@pertanian.go.id
}

\begin{abstract}
Abstrak
Adsorben dari limbah lignoselulosik menjadi alternatif di industri dikarenakan jumlah yang banyak dan mudah didapat. Karakteristik karbon aktif dari limbah lignoselulosik yang unik dan produksi massif yang lebih ekonomis menjadi alasan pengembangan produk samping dari limbah biosilika sekam padi ini. Tujuan dari penelitian adalah untuk memproduksi adsorben dari ampas ekstraksi nanobiosilika serbuk. Metode yang digunakan pada penelitian ini adalah kalsinasi (tanpa impregnasi) dan impregnasi dimana ampas sisa ekstraksi biosilika (200-300 g) direndam selama 24 jam dengan rasio limbah dan katalis 1:1 dan 1:2 $\mathrm{ZnCl}_{2}, \mathrm{H}_{3} \mathrm{PO}_{4}$, dan $\mathrm{KOH}$. kemudian dilakukan karbonisasi pada suhu $600^{\circ} \mathrm{C} ; 700^{\circ} \mathrm{C}$; dan $800^{\circ} \mathrm{C}$ selama 1 jam dan 3 jam dengan variasi ukuran mesh 10, 20, 80, dan 100 mesh. Hasil penelitian menunjukan bahwa ampas ekstraksi nanobiosilika masih mengandung $\mathrm{SiO}_{2}$ yang cukup tinggi $(89,86 \%)$ sehingga dapat dimanfaatkan sebagai bahan baku adsorber untuk aplikasi pada penjernihan air. Perlakuan kalsinasi menunjukan peningkatan daya serap dan peningkatan luas permukaan pori adsorben tertinggi. Ampas ekstraksi yang berukuran 100 mesh dan dikalsinasi pada suhu $800^{\circ} \mathrm{C}$ memiliki luas permukaan pori yang mendekati arang aktif komersial yaity $15,83 \mathrm{~m}^{2} / \mathrm{g}$.
\end{abstract}

Kata Kunci: Adsorben, lignoselulosik, biosilika, padi

\begin{abstract}
Adsorbent from lignocellulosic waste constitutes an alternative in industry due to the large amount and easy to get. The unique characteristics of activated carbon from lignocellulosic waste as well as more economically with regard to mass production were the reasons for the development of by-products of this rice husk biosilica waste. This research aimed to produce adsorbent from waste of nanobiosilica powder extraction. Calcination or treatment without impregnation) and with impregnation were applied in this study. Calcination was carried out by heating the residual waste at $600^{\circ} \mathrm{C} ; 700^{\circ} \mathrm{C}$; and $800^{\circ} \mathrm{C}$; however the impregnation process was carried out by immersing the residual waste with catalysts $\mathrm{ZnCl} 2, \mathrm{H} 3 \mathrm{PO} 4$, and $\mathrm{KOH}$ with ratio 1: 1 and 1: 2 for 24 hours. Subsequently, carbonisation was carried out at $600^{\circ} \mathrm{C}$; $700^{\circ} \mathrm{C}$; and $800^{\circ} \mathrm{C}$ for 1 and 3 hours with variations in mesh sizes of $10,20,80$, and 100 mesh. The results showed that the waste of nanobiosilica extraction still contained high $\mathrm{SiO} 2(89.86 \%)$ so that it could be used as raw material for adsorber to apply in water purification applications. The calcination treatment showed the highest absorption as well as the area of the pore surface. The best particle size was 100 mesh and calcined at $800^{\circ} \mathrm{C}$ in which has a pore surface area meet the requirement of commercial activated charcoal, which is $15.83 \mathrm{~m}^{2} / \mathrm{g}$.
\end{abstract} Keywords: Adsorbent, lignocellulosic, biosilica, paddy

\section{Pendahuluan}

Permintaan akan karbon aktif meningkat drastis sebagai agen untuk pemurnian air yang ramah lingkungan baik untuk air minum (Altenor et al., 2009; Bello-Huitle et al., 2010) dan juga untuk pengelolaan limbah air. Karbon aktif dari limbah lignoselulosik menjadi sumber alternatif prekursor dikarenakan jumlah yang banyak dan mudah didapat, karakteristik karbon aktif dari limbah lignoselulosik yang unik, dan produksi massive yang lebih ekonomis. Karbon aktif dari limbah tersebut digunakan untuk menghilangkan logam berat, warna, dan komponen fenol (Altenor et al., 2009). Limbah ekstraksi biosilika yang digunakan dalam penelitian ini masih mengandung $\mathrm{KOH}(\mathrm{pH}$ ampas 10) karena proses ekstraksi silika dilakukan menggunakan $\mathrm{KOH}$. $\mathrm{KOH}$ merupakan salah satu agen pengaktivasi. Hal ini memberikan keuntungan karena proses preparasi karbon aktif menjadi lebih singkat dan sederhana jika proses impregnasi oleh agen pengaktivasi tidak perlu dilakukan. Oleh karena itu, tahap pertama penelitian yang dilakukan adalah mengkarakterisasi bahan baku limbah sebagai by-product dari proses produksi nanobiosilika. Selain $\mathrm{KOH}$, agen pengaktivasi yang biasa digunakan adalah $\mathrm{H}_{3} \mathrm{PO}_{4}$ dimana mudah dihilangkan dengan air dingin atau panas setelah aktivasi karbon dan juga lebih mudah secara operasional dan ramah lingkungan. Tujuan dari kegiatan penelitian ini adalah untuk produksi karbon aktif dari limbah ekstraksi biosilika. 


\section{Bahan dan Metode Penelitian}

Ampas limbah produksi biosilika, arang sekam, dan abu sekam serta karbon aktif komersial. Menurut SNI 06-3730-1996 tahun 1995 tentang arang aktif, kadar air maksimal 15\%, kadar abu maksimal $10 \%$, kadar zat menguap maksimal $25 \%$, kadar karbon terikat minimal $65 \%$ dan daya serap terhadap iodin minimal $750 \mathrm{mg} / \mathrm{g}$.

Proses pembuatan karbon aktif dilakukan berdasarkan modifikasi Liu et al. (2016) dan Liu et al. (2018), dan Islam (2016). Tahapan penelitian adalah sebagai berikut:

\section{a. Karakterisasi bahan baku}

Ampas limbah produksi biosilika sebagai prekursor dikarakterisasi terlebih dahulu untuk mengetahui kadar C, H, O, N, Si dan S. Kemudian sebagai pembanding dikarakterisasi pula arang sekam dan abu sekam.

\section{b. Optimasi produksi karbon aktif}

Ampas sisa ekstraksi biosilika direaksikan dengan $\mathrm{HCl} \mathrm{3 \%} \mathrm{(w/v)} \mathrm{dengan} \mathrm{rasio} \mathrm{1:5} \mathrm{kemudian} \mathrm{diaduk} 30$ menit kemudian dibilas dengan aquades sehingga didapatkan $\mathrm{pH}$ netral. Kemudian Karbon aktif disaring, dikeringkan, dan ditimbang.

Pembuatan karbon aktif dilakukan pada kondisi pra-karbonisasi (tanpa impregrasi) dan dengan impregnasi dimana ampas sisa ekstraksi biosilika (200-300 g) direndam selama 24 jam dengan rasio limbah dan katalis $1: 1$ dan 1:2 kemudian dilakukan karbonisasi pada suhu $600^{\circ} \mathrm{C} ; 700^{\circ} \mathrm{C}$; dan $800^{\circ} \mathrm{C}$ selama 1 jam dan 3 jam dengan variasi ukuran mesh 10, 20, 80, dan 100 mesh. Sampel kemudian dikeringkan dan disimpan di desikator. Proses pembuatan karbon aktif pada penelitian ini disajikan pada Gambar 1.

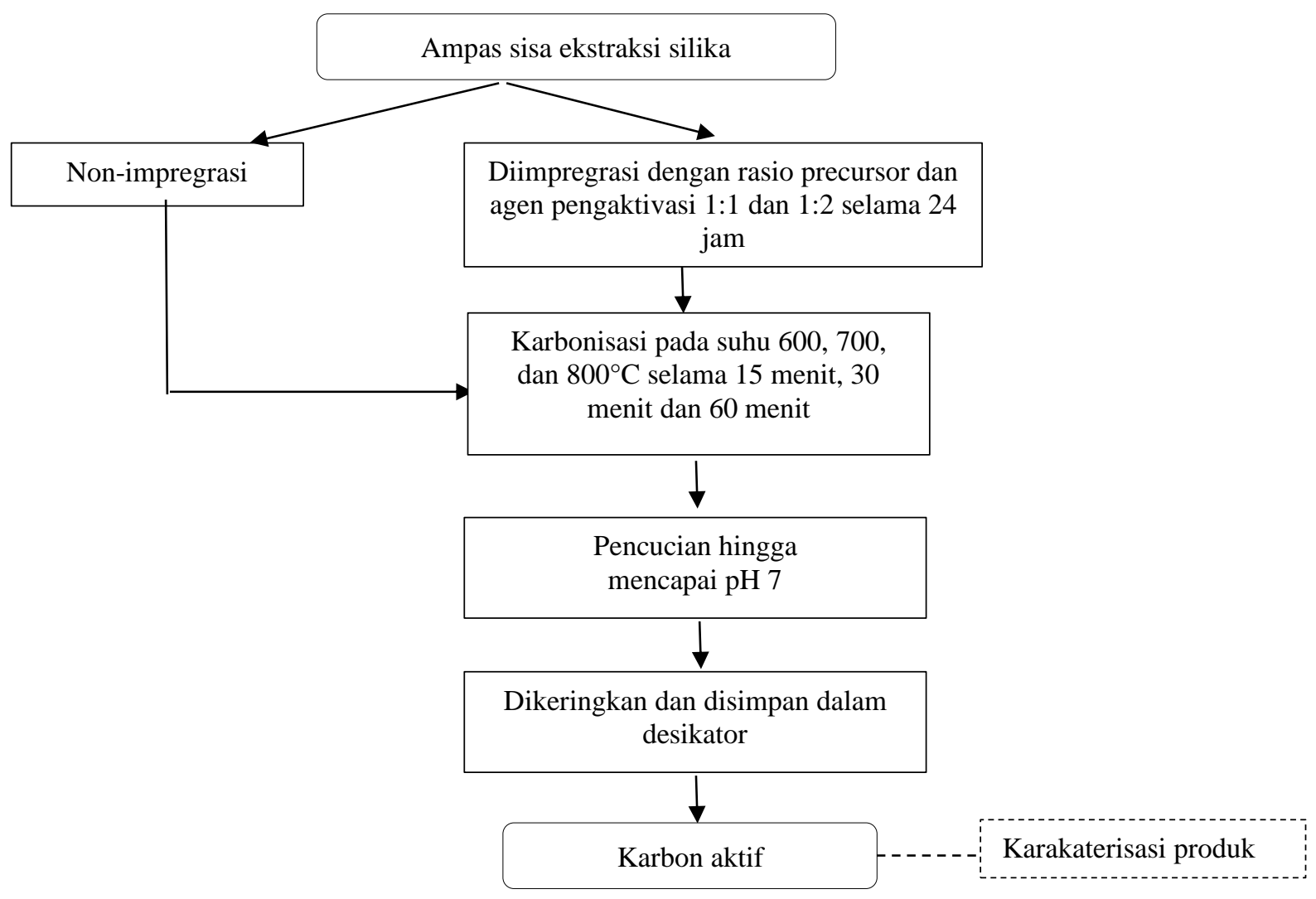

Gambar 1. Proses produksi karbon aktif

c. $\quad$ Karakterisasi karbon aktif:

Komposisi mineral produk karbon aktif menggunakan, ukuran pori dan luas permukaan spesifik (sehingga dapat melakukan identifikasi lebih lanjut untuk pengelolaan limbah air luas permukaan karbon aktif sekitar 100 to $1000 \mathrm{~m}^{2} / \mathrm{g}$ ), struktur mikroskopis, $\mathrm{pH}$, warna serta sifat absorpsi dengan pengujian daya serap iod. Karbon aktif komersial digunakan sebagai pembanding. Selain itu, dilakukan pula analisis

d. Aplikasi karbon aktif dilakukan pada proses penjernihan air berwarna

Aplikasi karbon aktif pada peneltian ini dilakukan pada penjernihan air destilat yang diberi pewarna makanan denga konsentrasi $0.2 \mathrm{ml}$. Karbon aktif dimasukkan ke dalam air berwarna dengan rasio 1:5 (w/v), diaduk dan didiamkan selama 1 jam, 2 jam, 3 jam, 4 jam, dan 24 jam. Kemudian 
disaring dua kali dan dianalisa warnanya menggunakan colorimeter. Sampling pengujian dilakukan setelah 4 jam dan 24 jam.

a. Aplikasi karbon aktif dilakukan pada proses penjernihan air dan air limbah

Aplikasi karbon aktif pada peneltian ini dilakukan pada penjernihan air dan air limbah. Karbon aktif dimasukkan ke dalam air sungai dan air limbah dengan rasio 1:25 (w/v), diaduk dan didiamkan selama 5 hari. Setelah itu, disaring dan air sungai/limbahnya dianalisa karakteristik fisik, kimia, dan mikrobiologisnya. Standar air bersih yang diacu sesuai dengan yang dikeluarkan oleh Badan Standar Nasional untuk kualitas air bersih (parameter fisika dan organik).

\section{Hasil Dan Pembahasan \\ a. Karakteristik}

Bahan baku pembuatan adsorben berbasis karbon aktif yang digunakan pada penelitian ini adalah limbah produksi biosilika melalui proses ekstraksi dengan $\mathrm{KOH}$, arang sekam, dan abu sekam. Karbon aktif komersial akan digunakan sebagai pembanding. Pembuatan karbon aktif ini melalui beberapa tahapan penelitian pendahuluan guna mencapai karbon aktif yang memenuhi syarat SNI 06-37301996 tahun 1995 tentang arang aktif. Arang aktif dari limbah pertanian telah banyak digunakan sebagai adsorben seperti sekam padi (1), daun ubi kayu (2), campuran jerami padi, kulit kacang-kacangan, dan sekam padi (3). Pemilihan adsorben dari limbah pertanian berkembang dikarenakan harganya yang relatif murah, jumlahnya banyak, dan mudah diakses. Namun, pemanfaatan biosorben karbon yang dibuat dari limbah pertanian, termasuk sekam padi, umumnya memiliki beberapa kelemahan seperti kapasitas adsorpsi relatif rendah, luas permukaan kecil, struktur mikropori terbatas, dan jalur difusi adsorbat (zat pencemar) ke dalam partikel padat (partikel adsorben) yang panjang (4)

Proses perpindahan massa pada permukaan poripori dalam butiran adsorben disebut adsorpsi (5). Perpindahan massa yang terjadi dapat melalui batas antara dua fasa yaitu : gas-padat dan cair-padat. Porositas adsorben menyerap adsorbat sangat menentukan efektifitas adsorben. Selain itu luas permukaan, distribusi pori, densitas Kamba, permukaan kimia, kekuatan $\mathrm{pH}$, densitas partikel, ukuran partikel, jumlah mineral larut dalam air serta kadar abu total (3).

Karakterisasi bahan baku adsorben telah dilakukan guna mengetahui kandungan komposisi kimia bahan. Karakteristik bahan baku disajikan pada Tabel 1 Berdasarkan data tersebut dapat diketahui bahwa kandungan C-organik pada ampas ekstraksi nanobiosilika sekitar 3\%, pada abu sekam adalah $4 \%$, dan pada arang sekam adalah $30 \%$. Nilai kandungan karbon tentu saja akan berpengaruh pada keberhasilan produk yang diinginkan. Namun, dapat kita lihat pula pada dua bahan baku awal yaitu ampas ekstraksi biosilika (AEB) dan abu sekam (ABS) mengandung kadar $\mathrm{SiO}_{2} 89 \%$ dan $85 \%$. Bagaimana pengaruh $\mathrm{C}$ dan $\mathrm{Si}$ pada pembuatan adsorben menjadi sangat menarik untuk diteliti lebih lanjut.

Tabel 1. Komposisi Kimia Ampas Ekstraksi Biosilika (AEB), Abu Sekam (ABS), Dan Arang Sekam (ARS)

\begin{tabular}{lccc}
\hline \multicolumn{1}{c}{ Parameter $(\%)$} & AEB & ABS & ARS \\
\hline Kadar air & $3,56 \pm 0,03$ & $9,09 \pm 0,08$ & $4,93 \pm 0,23$ \\
Kadar abu & $91,21 \pm 0.06$ & $84,06 \pm 0,28$ & $46,24 \pm 0,55$ \\
C-organik & $3,15 \pm 0.02$ & $4,37 \pm 0,13$ & $29,8 \pm 0,26$ \\
N-total & $0,31 \pm 0.02$ & $0,31 \pm 0,02$ & $1,12 \pm 0,03$ \\
C/N ratio & $10,50 \pm 0.71$ & $14,5 \pm 0,71$ & $26,5 \pm 0,71$ \\
S-total & $0,07 \pm 0.01$ & $0,06 \pm 0,01$ & $0,03 \pm 0,01$ \\
$\mathrm{SiO}_{2}$ & $89,86 \pm 0.15$ & $83,20 \pm 1,34$ & $43,98 \pm 0,13$ \\
\hline
\end{tabular}

Berdasarkan penelitian sebelumnya abu sekam padi yang kaya akan Silika $(60 \%)$ dan Karbon (10-40\%) digunakan sebagai adsorben (6), media filter, dan komponen katalisator. Silika merupakan bahan baku utama pada glass industry, keramik, untuk produksi larutan silikat, silikon dan alloy (7).

Pada dunia industri penggunaan silika gel sudah sangat luas, silika gel merupakan produk yang aman digunakan untuk menjaga kelembaban makanan, obat-obatan, bahan sensitif, elektronik dan film sekalipun. Produk anti lembab ini menyerap lembab tanpa merubah kondisi zatnya.

Pembuatan adsorben dari ampas ekstrasi (AEB) dilakukan dengan dua tahapan yaitu tanpa impregnasi dan impregnasi. Pada perlakuan tanpa impregnasi dilakukan penelitian pendahuluan dengan aktivasi (kalsinasi) pada suhu $600{ }^{\circ} \mathrm{C}$ selama 1 jam. adsorpsi fisik, yaitu partikel partikel adsorbat mendekat ke permukaan adsorben melalui gaya Van der Waals atau melalui ikatan hidrogen (5). Hal ini dilakukan untuk meningkatkan kapasitas adsorpsi AEB dengan memperkecil ukuran pori dan luas permukaannya (8)

Berdasarkan data pada Gambar 2-b dapat dilihat bahwa struktur karbon aktif komersial sangat teratur dan banyak memiliki pori-pori kecil. Besarnya ukuran pori akan sangat menentukan daya adsorbansi dari karbon aktif. Semakin kecil pori maka semakin besar luas permukaan dan semakin tinggi daya adsorpsinya. Hal ini sesuai dengan penelitian sebelumnya yang melaporkan bahwa Pada karbon aktif berupa bubuk, semakin besar luas area permukaan pori adsorben maka daya adsorpsinya juga semakin besar (9).

Semakin besar luas permukaan karbon aktif maka semakin besar kemampuan adsorpsi karbon aktif. Sedangkan struktur mikroskopis AEB pada Gambar 2-a terlihat tidak teratur dan hanya 
memiliki sedikit pori-pori. Namun, setelah dilakukan kalsinasi pada suhu $600{ }^{\circ} \mathrm{C}$ selama 1 jam maka struktur AEB tampak lebih jelas memiliki pori-pori lebih banyak dan lebih teratur (Gambar 2- c). Hal ini sesuai dengan hasil penelitian sebelumnya bahwa pada, semakin tinggi suhu maka semakin tinggi luas permukaan.
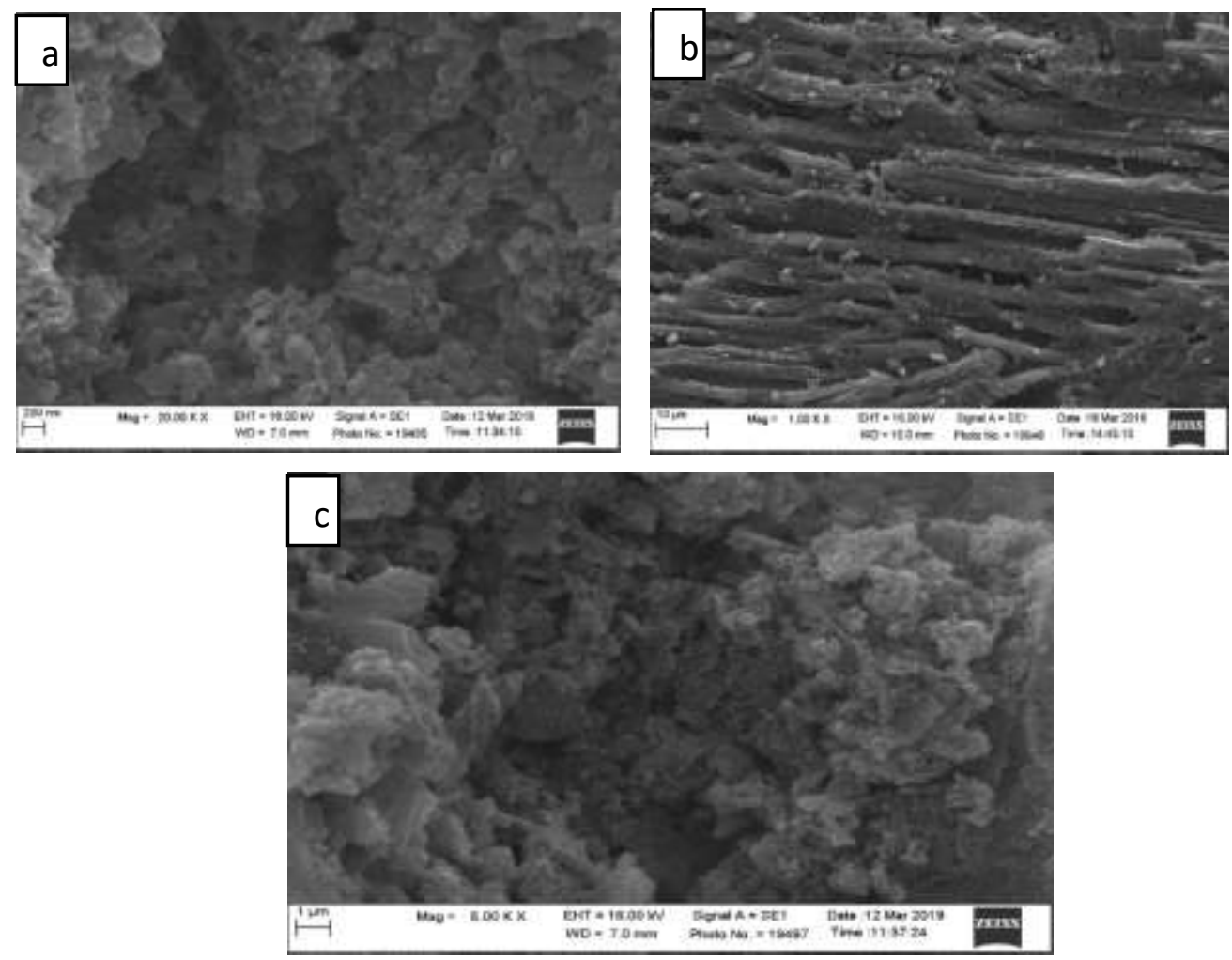

Gambar 2. Struktur mikroskopik AEB (M 20000x) (a); karbon aktif komersial (M 1000x) (b); dan AEB setelah kalsinasi 1 jam pada suhu $600{ }^{\circ} \mathrm{C}$ (M 5000x)

Bahan baku adsorben kemudian dikarakterisasi daya serap iodnya untuk mengetahui kapasitas daya serap dan luar pemukaan karbon aktif tersebut. Semakin tinggi daya serap iodium maka semakin banyak mikropori yang terbentuk pada arang aktif Berdasarkan hasil analisa daya serap iod pada Gambar 3 memiliki daya serap iodine yang rendah dari pada karbon aktif komersial $(850 \mathrm{mg} / \mathrm{g}$ ) yaitu berkisar antara 260-336 mg/g. Tinggi rendahnya daya serap arang aktif terhadap iodium dapat dilihat dari angka iodin (iodine number) yang diperoleh (10). Sedangkan sesuai SNI karbon aktif komersial memiliki syarat daya serap iod $>750$ $\mathrm{mg} / \mathrm{g}$. Sehingga, ketiga bioadsorber belum memenuhi syarat SNI tersebut dan perlu dilakukan proses aktifasi untuk meningkatkan kapasitas daya adsorpsinya.
Proses aktifasi merupakan hal yang penting diperhatikan disamping bahan baku yang digunakan. Aktifasi adalah suatu perlakuan terhadap bahan adsorber yang bertujuan untuk memperbesar pori-pori dengan cara memecahkan ikatan hidrokarbon atau mengoksidasi molekul-molekul permukaan, sehingga bahan mengalami perubahan sifat, baik fisika maupun kimia, luas permukaannya bertambah besar dan berpengaruh. perlu dilakukan untuk meningkatkan luas permukaan dan daya adsorpsi karbon aktif. Hasil aktifasi bahan adsorber AEB dengan kalsinasi 1 jam menunjukan luas permukaan yang lebih tinggi dari ARS dan ABS. Padahal dari hasil karakterisasi bahan baku AEB pada Tabel 1 mengandung lebih banyak Silika (89\%). Tahap aktifasi dapat menurunkan unsur pengotor dalam hal ini oksida logam (8). 


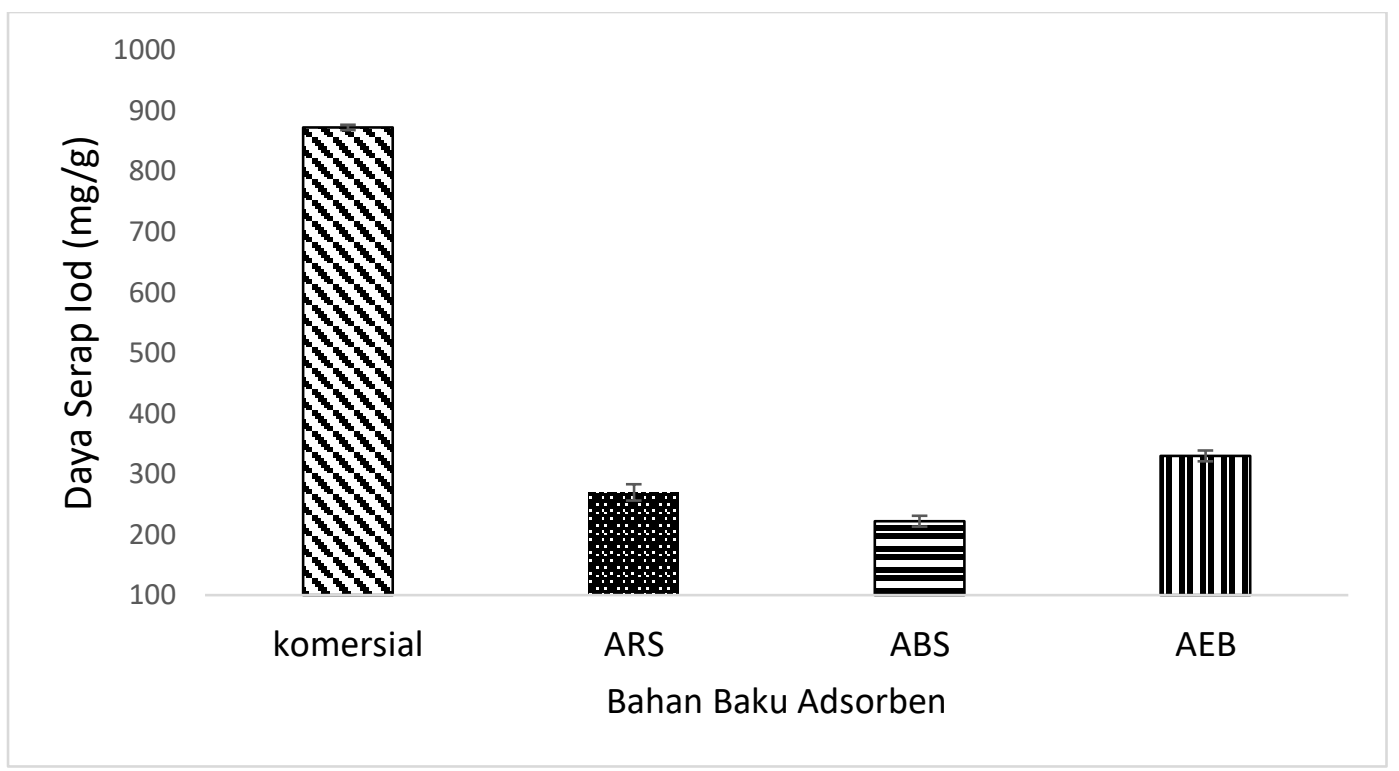

Gambar 3. Daya serap iod bahan baku adsorben

Selain daya serap iod, kemudian diukur pula luas permukaan daya serap iod dari ketiga bahan adsorber dan komersial adsorber dalam penelitian ini seperti tampak pada Tabel 2. Daya serap arang aktif merupakan suatu akumulasi atau terkonsentrasinya komponen di permukaan/antar muka dalam dua fasa (11).

Luas permukaan daya serap iodine ketiga bahan adsorber penelitin ini masih rendah dibandingkan komersial. Di sisi lain, hasil analisa ini pun menunjukan bahwa AEB memiliki luas permukaan dan nilai daya serap iodine yang lebih tinggi dibandingkan ABS dan ARS. Sehingga, AEB memiliki kemampuan adsorber yang paling baik dibandingkan ABS dan ARS. Oleh karena itu, selanjutnya AEB digunakan sebagai bio-adsorber terpilih dengan optimasi produksi bio-adsorber dengan perlakuan suhu, waktu kalsinasi, dan ukuran partikel guna meningkatkan daya serap dan luas permukaan adsorber.

Tabel 2. Hasil analisa daya serap iod

\begin{tabular}{|l|c|}
\hline \multicolumn{1}{|c|}{ Sampel } & Luas Permukaan $\left(\mathrm{x} 10^{5} \mathrm{~m}^{2} / \mathrm{g}\right)$ \\
\hline Arang sekam (ARS) & $5,12 \pm 0,26$ \\
\hline Abu sekam (ABS) & $4,21 \pm 0,17$ \\
\hline Ampas ekstraksi (AEB) & $6,26 \pm 0,17$ \\
\hline Arang aktif komersial & $16,56 \pm 0,09$ \\
\hline
\end{tabular}

\section{b. Optimasi produksi bio-adsorber berbasis Ampas Ekstraksi Biosilika (AEB)}

Bioadsorber yang digunakan pada penelitian ini adalah ampas eksraksi biosilika (AEB) dimana pada penelitian pendahuluan memiliki daya adsorpsi dan luas permukaan paling tinggi jika dibandingkan abu sekam dan arang sekam. Untuk meningkatkan kapasitas adsorben maka waktu kalsinasi, suhu kalsinasi, dan ukuran partikel menjadi perlakuan pada penelitian ini. Kalsinasi merupakan proses pemanasan suatu benda hingga temperaturnya tinggi, tetapi masih di bawah titik lebur untuk menghilangkan kandungan yang dapat menguap (12). Proses ini dapat memperbaiki struktur bio-adsorben. Pada penelitian ini, waktu kalsinasi ditingkatkan menjadi 3 jam dengan suhu kalsinasi 600,700 , dan $800{ }^{\circ} \mathrm{C}$. Proses kalsinasi pada dapat memperbaiki struktur, menguapkan molekul air dan senyawa organik yang terikat pada struktur adsorber, sehingga dapat membuka pori dan meningkatkan luas permukaan. Kemudian ukuran partikel bio-adsorber adalah 10, 20, 80, dan 100 mesh. Ruang pori yang sangat banyak dengan ukuran tertentu dapat menangkap partikel-partikel yang akan diserap

Daya serap iod dengan waktu kalsinasi 1 dan 3 jam pada suhu 600,700 , dan $800{ }^{\circ} \mathrm{C}$, serta ukuran partikel 10, 20, 80, dan 100 mesh dapat dilihat pada Gambar 4. Data menunjukkan bahwa bio-adsorber pada waktu kalsinasi 1 jam memiliki daya serap iod tertinggi pada suhu kalsinasi $800{ }^{\circ} \mathrm{C}$ yaitu 472-510 mg/g. Namun, setelah waktu kalsinasi ditingkatkan menjadi 3 jam maka daya serap iod meningkat menjadi $637-834 \mathrm{mg} / \mathrm{g}$. Berdasarkan data tersebut maka waktu kalsinasi 3 jam adalah waktu terbaik. Kemudian suhu kalsinasi terbaik adalah 800 
${ }^{\circ} \mathrm{C}$. Hal ini kemungkinan dikarenakan pada temperatur ini dapat menguapkan molekul air dan senyawa organik yang terikat pada struktur Silika Oksida, sehingga dapat membuka pori dan meningkatkan luas permukaan. Sedangkan ukuran partikel terbaik adalah 100 mesh. Hal ini menunjukan bahwa proses penyerapan adsorben terhadap adsorbat lebih cepat karena secara teoritis semakin kecil ukuran partikel, maka luas permukaan adsorben akan bertambah luas sehingga akan lebih mudah terserap pada permukaan adsorben (5).

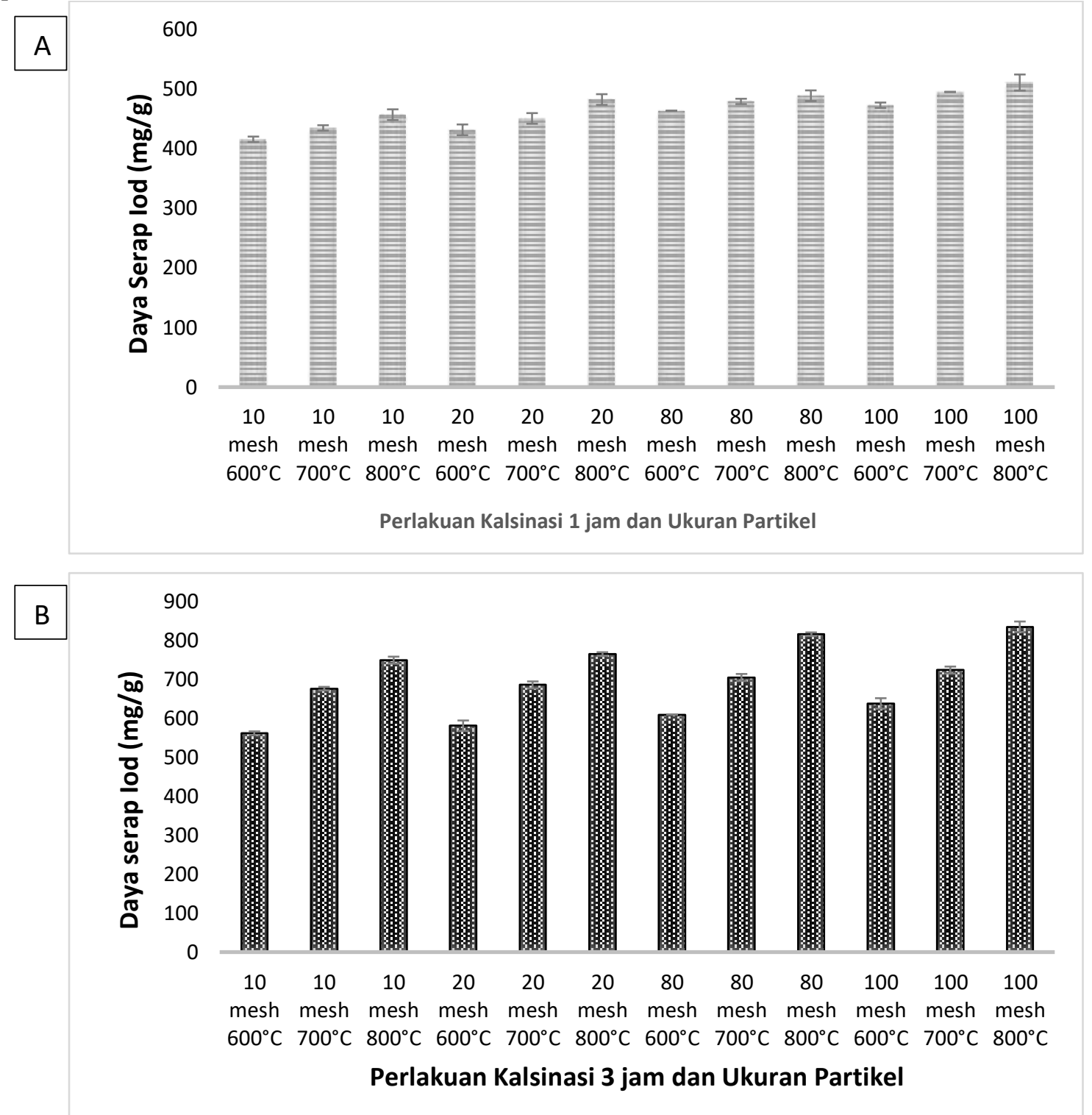

Gambar 4. Daya serap iod pada suhu 600,700 , dan $800^{\circ} \mathrm{C}$, serta ukuran partikel 10, 20, 80, dan 100 mesh dengan waktu kalsinasi 1 (A) dan 3 jam (B)

Berdasarkan data diatas maka meningkatnya suhu dan waktu kalsinasi akan meningkatkan daya serap iod bioadsorben AEB, hal ini juga sejalan dengan peningkatan luas permukaannya seperti terlihat pada Tabel 3. Luas permukaan tertinggi terdapat pada bio-adsorben dengan perlakuan 3 jam, suhu kalsinasi $800{ }^{\circ} \mathrm{C}$, dan ukuran partikel 100 mesh yaitu sebesar $14,51 \times 10^{5}$ $\mathrm{m}^{2} / \mathrm{g}$. 
Tabel 3. Hasil Perbandingan Uji Iodine ampas ekstraksi (AE) Kalsinasi 1 jam dan 3 jam dengan perlakuan berbagai ukuran partikel dan suhu kalsinasi

\begin{tabular}{|l|l|c|c|}
\hline Perlakuan Suhu & Perlakuan Mesh & $\begin{array}{c}\text { Luas Permukaan pada } \\
\text { waktu kalsinasi 1 jam } \\
\left(\mathbf{x 1 0}^{\mathbf{5}} \mathbf{~ m}^{2} \mathbf{g}\right)\end{array}$ & $\begin{array}{c}\text { Luas Permukaan pada } \\
\text { waktu kalsinasi 3 jam } \\
\left(\mathbf{x 1 0}^{\mathbf{5}} \mathbf{m}^{2} / \mathbf{g}\right)\end{array}$ \\
\hline $600^{\circ} \mathrm{C}$ & 10 & 7.886 & 10.655 \\
\hline & 20 & 8.247 & 12.822 \\
\hline & 80 & 8.669 & 14.207 \\
\hline $700^{\circ} \mathrm{C}$ & 100 & 8.187 & 11.017 \\
\hline & 10 & 8.247 & 12.822 \\
\hline & 20 & 8.669 & 14.207 \\
\hline & 80 & 8.187 & 11.017 \\
\hline $800^{\circ} \mathrm{C}$ & 100 & 8.548 & 13.003 \\
\hline & 10 & 8.669 & 14.207 \\
\hline & 20 & 8.187 & 11.017 \\
\hline & 80 & 8.548 & 13.003 \\
\hline & 100 & 9.150 & 14.508 \\
\hline
\end{tabular}

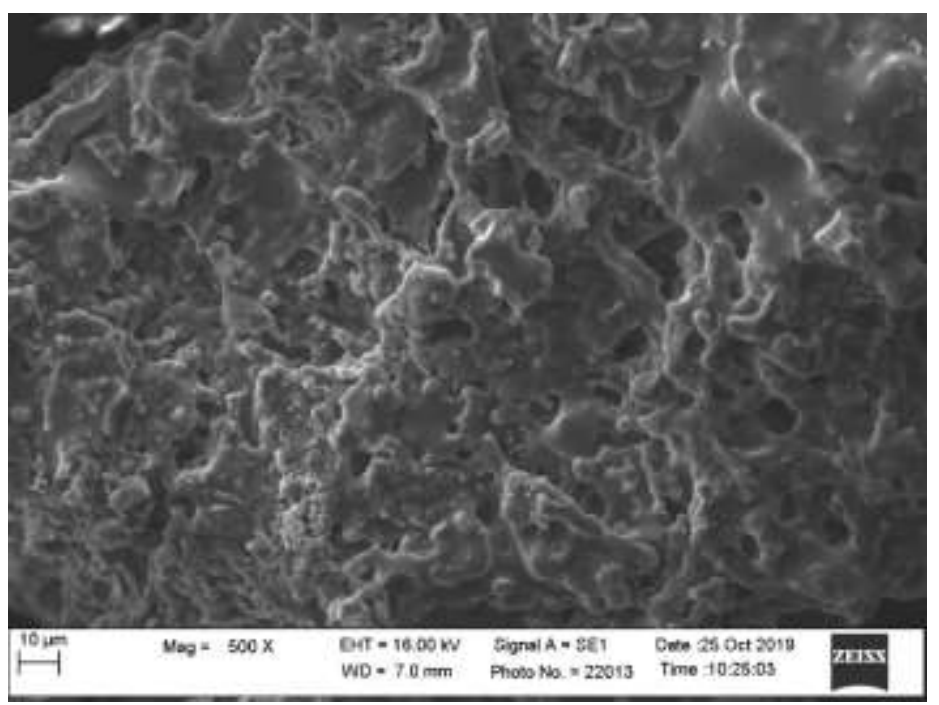

Gambar 5. Struktur mikroskopis bio-adsorben ampas ekstraksi biosilika (AEB) waktu kalsinasi 3 jam, suhu kalsinasi 800 oC, dan ukuran partikel 100 mesh (M 500x).

\section{c. Proses aktifasi AEB dengan impregnasi}

Selain proses kalsinasi, untuk menigkatkan kapasitas adsorbansi AEB, maka dilakukan pula proses impregnasi dengan berbagai zat activator antara lain $\mathrm{KOH}, \mathrm{ZnCl}_{2}$, dan $\mathrm{H}_{3} \mathrm{PO}_{4}$. Proses impregnasi merupakan metode penjenuhan zat tertentu secara total dengan mengisi pori-pori penyangga dalam larutan logam aktif melalui adsorbsi logam (merendam penyangga dalam larutan logam aktif). Penyangga berfungsi sebagai penyedia permukaan luas yang memudahkan menebar sisi aktif, sehingga kontak yang terjadi lebih luas dan efisien. Metode impregnasi juga sangat cocok untuk katalis dengan persen berat komponen aktif katalis yang kecil, yaitu komponen aktif yang termasuk logam mulia namun diinginkan terdistribusi sempurna sehingga diperoleh luas permukaan komponen aktif yang besar (2). 


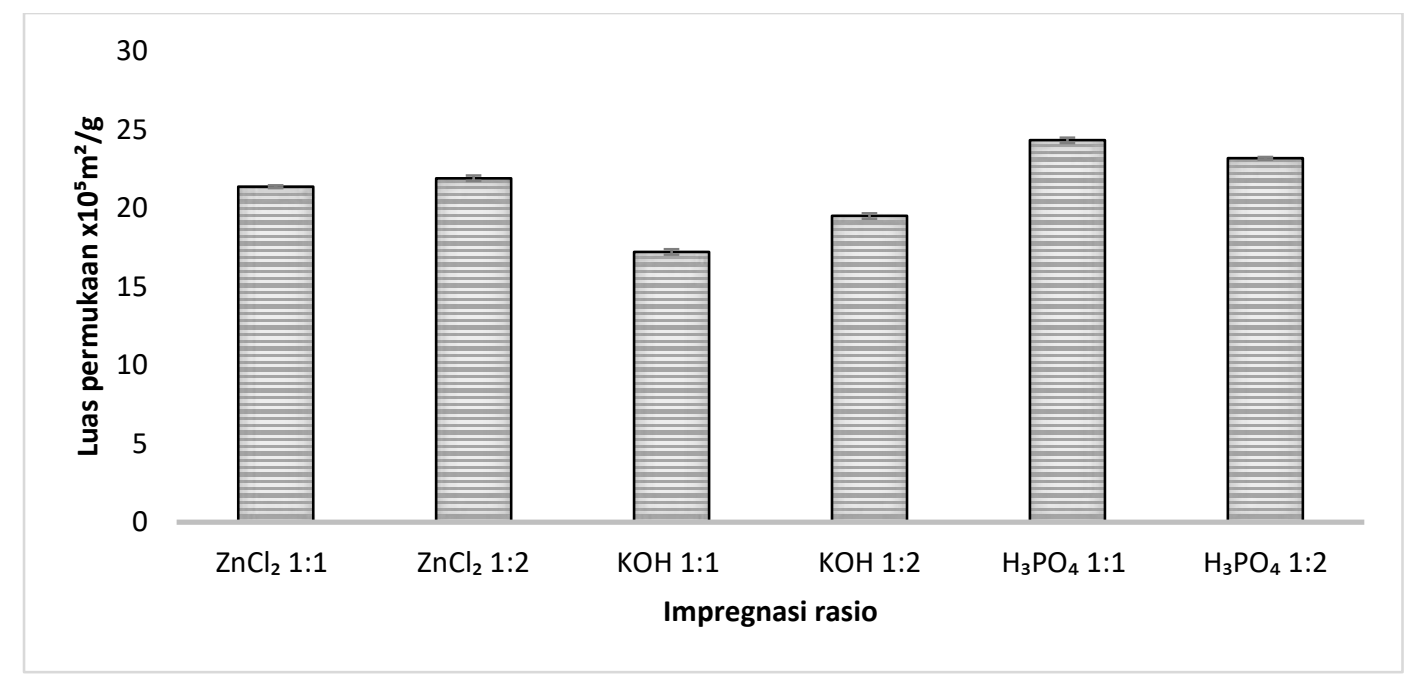

Gambar 6. Luas permukaan AEB dengan zat activator $\mathrm{ZnCl}_{2}, \mathrm{KOH}$, dan $\mathrm{H}_{3} \mathrm{PO}_{4}$ dengan rasio 1:1 dan 1:2

Berdasarkan data pada Gambar 6 bahwa proses impregnasi AEB terbaik adalah menggunakan zat activator $\mathrm{H}_{3} \mathrm{PO}_{4}$ dengan rasio 1:1 dengan luas permukaannya sebesar $24 \times 10^{5} \mathrm{~m}^{2} / \mathrm{g}$.
Sedangkan pada Gambar 7 data menunjukkan bahwa daya serap iod pun dihasilkan oleh AEB dengan menggunakan zat activator $\mathrm{H}_{3} \mathrm{PO}_{4}$ rasio $1: 1$ yaitu sebesar $1281 \mathrm{mg} / \mathrm{g}$.

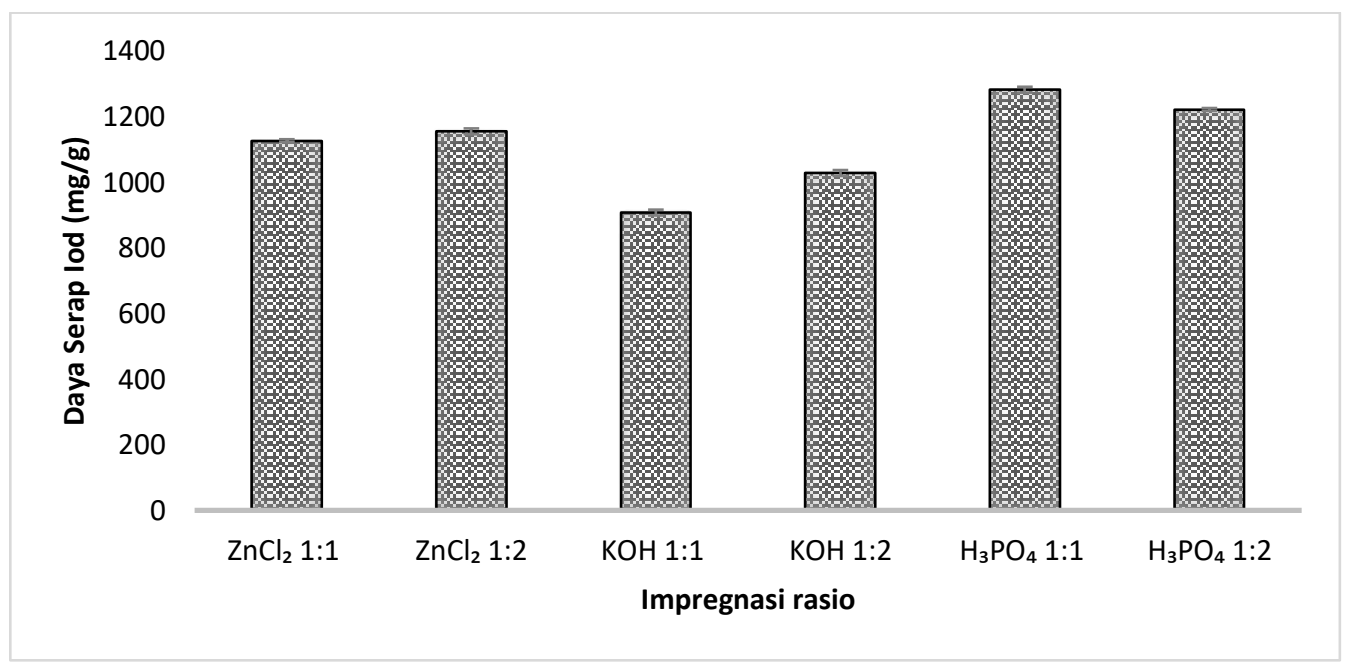

Gambar 7. Daya serap iod AEB dengan zat activator $\mathrm{ZnCl}_{2}, \mathrm{KOH}$, dan $\mathrm{H}_{3} \mathrm{PO}_{4}$ dengan rasio 1:1 dan 1:2

Aktivasi AEB secara kimia bertujuan menghilangkan logam-logam pengotor dengan larutan asam phospat yang kaya hidrogen $(\mathrm{H})$ dan atom $\mathrm{H}$ mudah ditukar dengan kation lain sehingga menyebabkan terbukanya pori yang tertutup pengotor organik akan meningkatkan luas permukaan. Hal ini diperkuat dengan struktur mikroskopis impregnasi dengan $\mathrm{H}_{3} \mathrm{PO}_{4}$ yang menunjukan semakin teraturnya struktur dan meningkatnya pori-pori adsorben dan luas permukaannya seperti tampak pada Gambar 8. 


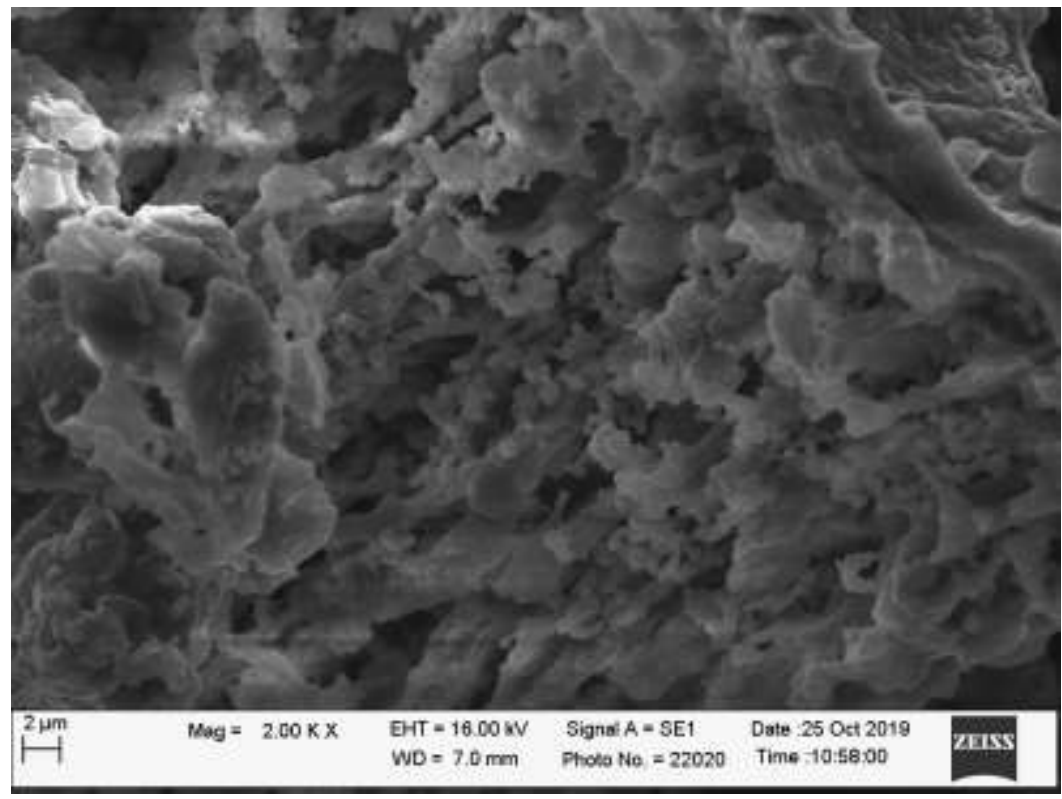

Gambar 7. Struktur mikroskopis Bioadsorben AEB dengan impregnasi $\mathrm{H}_{3} \mathrm{PO}_{4}$ rasio 1:1

Karakterisasi produk adsorber AEB proses kalsinasi dan impregnasi terbaik kemudian dikarakterisasi seperti tampak pada Tabel 4. Data menunjukkan bahwa bioadsorben terbaik pada penelitian ini telah memenuhi syarat sebagai adsorber berbasis karbon aktif.

Tabel 4. Karakteristik produk adsorben AEB dengan kalsinasi dan impregnasi

\begin{tabular}{|l|l|l|l|}
\hline \multicolumn{1}{|c|}{ Parameter (\%) } & AEB kalsinasi terbaik & \multicolumn{1}{|c|}{$\begin{array}{c}\text { AEB impregnasi } \\
\text { terbaik }\end{array}$} & \multicolumn{1}{|c|}{$\begin{array}{c}\text { SNI 06-3730 } \\
\text { Karbon Aktif }\end{array}$} \\
\hline Kadar air & 0.95 & 1.29 & Maks 15\% \\
\hline Kadar abu & 21.47 & 51 & Maks 10\% \\
\hline $\begin{array}{l}\text { Kadar zat mudah } \\
\text { menguap }\end{array}$ & 0.23 & 0.15 & Maks 25\% \\
\hline Daya serap Iod (mg/g) & 847 & 1281 & Min 750 \\
\hline
\end{tabular}

\section{Kesimpulan}

Berdasarkan hasil penelitian, ampas ekstraksi nanobiosilika masih mengandung $\mathrm{SiO}_{2}$ yang cukup tinggi $(89,86 \%)$ sehingga dapat dimanfaatkan sebagai bahan baku adsorber untuk aplikasi pada penjernihan air. Peningkatan daya serap dilakukan melalui proses kalsinasi dimana ukuran bahan yang semakin kecil dan suhu kalsinasi yang semakin meningkat memberikan peningkatan luas permukaan pori. Ampas ekstraksi yang berukuran 100 mesh dan dikalsinasi pada suhu $800^{\circ} \mathrm{C}$ memiliki luas permukaan pori yang mendekati arang aktif komersial $\left(15,83 \mathrm{~m}^{2} / \mathrm{g}\right)$.

\section{Daftar Pustaka}

1. Cheenmatchaya A, Kungwankunakorn S. Preparation of Activated Carbon Derived from Rice Husk by Simple Carbonization and Chemical Activation for Using as Gasoline Adsorbent. Int $\mathrm{J}$ Environ Sci Dev.
2014;5(2):171-5.

2. Samson Maria Louis N, Thomas S. Activated carbon from tapioca leaves for treating dye waste water. Toxicol Environ Health Sci. 2013;5(3):131-7.

3. Ahmedna M, Johns MM, Clarke SJ, Marshall WE, Rao RM. Potential of agricultural byproduct-based activated carbons for use in raw sugar decolourisation. J Sci Food Agric. 1997;75(1):117-24.

4. Sulyman M, Namiesnik J, Gierak A. Low-cost adsorbents derived from agricultural byproducts/wastes for enhancing contaminant uptakes from wastewater: A review. Polish J Environ Stud. 2017;26(2):479-510.

5. Arif AR, Saleh A, Saokani J. Adsorpsi karbon aktif dari tempurung kluwak (Pangium edule) terhadap penurunan fenol. Al-Kimia. 2015;3(1):34-47.

6. Shen Y, Zhao P, Shao Q. Porous silica and carbon derived materials from rice husk pyrolysis char. Microporous Mesoporous Mater. 2014;188:46- 
76.

7. Ahiduzzaman M, Sadrul Islam AKM. Preparation of porous bio-char and activated carbon from rice husk by leaching ash and chemical activation. Springerplus. 2016;5(1).

8. Yuliusman Y, Purwanto WW, Nugroho YS. Pemilihan Adsorben Untuk Penjerapan Karbon Monoksida Menggunakan Model Adsorpsi Isotermis Langmuir. Reaktor. 2013;14(3):225.

9. Arsad E. Teknologi Pengolahan Dan
Pemanfaatan Karbon Aktif Untuk Industri. J Ris Ind Has Hutan. 2010;2(2):43.

10. Imawati A, Adhitiyawarman. Kapasitas Adsorpsi Maksimum Ion $\mathrm{Pb}$ ( II ). Jkk. 2015;4(2):50-61.

11. Mody L. Pembuatan Dan Kegunaan Arang Aktif. Info Tek EBONI. 2014;11(2):65-80.

12. Dewi TK, Novriyansyah T. Dan Suhu Reduksi Terhadap Karakter Katalis Kobalt / Zeolit Alam Aktif. 2016;22(3). 